\title{
RECOVERY OF MEMORY AFTER CEREBRAL ARTERY ANEURYSM SURGERY
}

\author{
Ljiljana Pačić-Turk ${ }^{1}$, Petra Jandrijević ${ }^{2}$ and Ana Havelka-Meštrović ${ }^{3}$ \\ ${ }^{1}$ Department of Psychology, Catholic University of Croatia, Zagreb, Croatia; ${ }^{2}$ Cvjetno naselje Elementary School, \\ Zagreb, Croatia; ${ }^{3}$ Rochester Institute of Technology Croatia, Zagreb, Croatia
}

\begin{abstract}
SUMMARY - The principal study objective was to define whether memory deficits (numerical, working, verbal-mechanical, verbal-logical and visual memory) occurred in patients submitted to surgery for brain artery aneurysm and whether significant recovery of memory took place with time. The study sample included 92 patients, i.e. 35 (38\%) male and 57 (62\%) female patients aged 27 to 76 years. Neuropsychological testing was conducted at Zagreb University Hospital Centre, Department of Neurosurgery, from 1998 to 2012, in two time intervals: first within 11 months following surgery, and then 12 to 48 months after surgery. The obtained results showed that verbal-mechanical, verballogical, and visual memory deficits were present in the first testing interval. In the second testing, the verbal-logical and visual memory deficits were still present, while the tests of verbal-mechanical memory showed deficits in capacity and learning curve, but the results for short- and long-term memory were within the normal ranges. Neither the first nor the second testing showed deficits of numerical and working memory. Based on our results, we can conclude that long-term verbal-mechanical and visual short- and long-term memory had recovered to a statistically significant level, whereas other types of memory showed no significant recovery.
\end{abstract}

Key words: Intracranial aneurysm - surgery; Memory, short-term; Memory, long-term; Memory disorders; Recovery of function; Croatia

\section{Introduction}

The consequences of cerebrovascular diseases are manifested in cognitive and conative, as well as in motor functioning of an individual and significantly affect the patient's quality of life. After the surgery, many patients cannot return to their jobs and completely depend on other people's assistance, thus causing social problems in their living environment ${ }^{1}$. The incidence of cerebral aneurysm ranges from 10 to 16 per 100 $000^{2}$, while deficits of mental functions usually occur as a consequence of subarachnoid hemorrhage (SAH) caused by ruptured aneurysm ${ }^{3}$. According to Halligan et al. ${ }^{4}$, the objective of neuropsychological evaluation is

Correspondence to: Assist. Prof. Ljiljana Pačić-Turk, PhD, Department of Psychology, Catholic University of Croatia, Ilica 242, HR10000 Zagreb, Croatia

E-mail:1jpturk@unicath.hr

Received January 24, 2018, accepted February 19, 2018 to identify cognitive, emotional and behavioral sequels of cerebral dysfunctions. Despite satisfactory neurological recovery, the patients often continue to complain of subjective disorder, particularly in terms of memory deficiency, concentration and tiredness. The multiple role of a neuropsychologist among all includes determination of cognitive and conative changes and monitoring the patient's recovery, especially in different stages of neuropsychological rehabilitation ${ }^{5}$. Neuropsychological assessment of patients suspect of memory disorder includes tests of memorizing information obtained through different modalities, visual, auditory and tactile. Each modality is tested by using the tasks of short- and long-term memory ${ }^{6}$. Stenhouse et al. ${ }^{7}$ state that in patients with $\mathrm{SAH}$ resulting from rupture of anterior communicating artery aneurysm (ACoA), the so-called amnesic syndrome occurs quite often and leads to poor social adjustment. These results are in accordance with Okawe et al. ${ }^{8}$ study results, 
showing that patients with $\mathrm{ACoA}$ aneurysm and $\mathrm{SAH}$ exhibited changes in cognitive functioning and personality. The so-called amnesic syndrome is characterized by amnesia, personality changes, executive function deficits and confabulations ${ }^{9}$. Similarly, Ljunggren et al. ${ }^{10}$ found significant changes in intellectual functions, memory, visual and spatial abilities, speed and accuracy of perception, and formation of ideas; the consequences could also be seen in social activities, emotional control and mood. Further, Stenhouse et al. ${ }^{7}$ conducted neuropsychological testing 12-84 months following $\mathrm{ACoA}$ aneurysm and the results showed that rupture of aneurysm in the medial brain artery often resulted in disorders of speech, spatial abilities and memory, while the consequences of ACoA aneurysm rupture often led to memory problems and personality changes. A significant number of patients have longterm cognitive deficits after $\mathrm{ACoA}$ aneurysm surgery. Fontanella et al. ${ }^{11}$ also found that the most common deficits occurring after $\mathrm{ACoA}$ aneurysm surgery were those related to memory. Although short-term memory can remain intact or only mildly damaged, longterm memory becomes significantly deficient regardless of the deficit referring to verbal or visuospatial information. Also, these patients have poorer results in tests of recollection than in recognition tests.

Haug et al. ${ }^{12}$ report on the follow up of cognitive functions in patients at 3-, 6- and 12-month intervals after aneurysmal $\mathrm{SAH}$, and their correlation with these time intervals. The results showed that complete cognitive recovery from aneurysmal SAH varied significantly. Three months after SAH, all of the examined cognitive functions showed mild or moderate damage, whereas the majority of cognitive functions improved after one year. The authors further state that motor and psychomotor functions can recover within the first 6 months, while verbal memory shows no recovery at all within these 6 months. Ohue et al..$^{13}$ assessed mental functions in patients with non-ruptured aneurysm preoperatively and one month following surgery. Their results suggested that neuropsychological outcomes following surgery of non-ruptured brain artery aneurysm were not satisfactory, particularly in view of significant memory deficits occurring after surgery.

Since memory deficits and those of executive functions are among the most commonly found deficits following rupture of ACoA aneurysm, Simard et al. ${ }^{14}$ studied episodic and semantic memory, and the results showed that patients with poor functioning of the frontal lobe showed significant deficits in free recollection tasks (immediate and postponed).

Tooth et al. ${ }^{15}$ evaluated 62 patients 12 months after aneurysm surgery and found deficits in a number of tests of intellectual functions, all tests of memory functions and many tests of executive functions. Ørbo et al. ${ }^{16}$ confirmed severe deficits in memory, executive functions and speed of processing. Almost identical results were obtained by Al-Khindi et al. ${ }^{17}$ in their meta-analysis of long-term consequences of aneurysmal SAH related to cognitive functions and everyday living functioning. They analyzed the results of 61 studies conducted in the past 10 years focusing on the effects of aneurysmal SAH and confirming severe memory (approximately 60\%), executive functions (up to $75 \%$ ) and speech (up to $75 \%$ ) deficits. Intelligence tests show no significant deterioration after $\mathrm{SAH}$, but indicate the possibility of false-negative finding mostly due to the significant lack of sensitivity of the tests available ${ }^{18}$. However, Otawara et al. ${ }^{19}$ carried out a study that included assessment of cognitive functioning of patients before and after surgery of non-ruptured intracranial aneurysm and report opposite results; the patients did not develop any cognitive disorders after operative procedure.

The objective of our study was to investigate memory deficits and the course of its recovery in Croatian patients operated for brain aneurysms at Department of Neurosurgery, Zagreb University Hospital Centre. The principal objective of our study was to find out whether memory deficits (numerical, working, verbalmechanical, verbal-logical and visual) occurred within the first 11 months and then from 12 to 48 months after SAH and surgery of brain artery aneurysms, and also whether the functions recovered with time, i.e. whether these memory deficits diminished with time.

\section{Subjects and Methods}

\section{Subjects}

The study included 92 patients, 35 (38\%) male and 57 (62\%) female patients. Neuropsychological testing was carried out in the period from 1998 to 2012 at Department of Neurosurgery, Zagreb University Hospital Centre. Exclusion criteria were pre-morbid dis- 
Table 1. Study participants according to types of brain aneurysm surgery

\begin{tabular}{|c|c|c|}
\hline & & $\mathrm{f}$ \\
\hline \multirow{3}{*}{$\begin{array}{l}\text { Number of } \\
\text { operations }\end{array}$} & One operation & 83 \\
\hline & Two operations & 5 \\
\hline & More than two operations & 3 \\
\hline \multirow{3}{*}{$\begin{array}{l}\text { Brain } \\
\text { hemisphere }\end{array}$} & Left & 44 \\
\hline & Right & 32 \\
\hline & Left and right & 15 \\
\hline \multirow{2}{*}{$\begin{array}{l}\text { Number of } \\
\text { aneurysms }\end{array}$} & One aneurysm & 77 \\
\hline & Multiple aneurysms & 15 \\
\hline
\end{tabular}

$\mathrm{f}=$ frequency

Table 2. Study participants according to aneurysm location

\begin{tabular}{|l|l|l|l|}
\hline Aneurysm location & $\mathrm{f}$ & Male (n) & Female (n) \\
\hline ACoA & 33 & 13 & 20 \\
ACA & 1 & 1 & 0 \\
ACM & 26 & 11 & 15 \\
ACI & 9 & 3 & 6 \\
AB & 1 & 0 & 1 \\
Other & 7 & 2 & 5 \\
Multiple arteries & 15 & 5 & 10 \\
\hline
\end{tabular}

$\mathrm{f}=$ frequency; $\mathrm{ACoA}=$ anterior communicating artery aneurysm; $\mathrm{ACA}=$ anterior artery aneurysm; $\mathrm{ACM}=$ medial artery aneurysm; $\mathrm{ACI}=$ internal carotid artery aneurysm; $\mathrm{AB}=$ basilar artery aneurysm

orders related to central nervous system diseases with lesions to the central nervous system or requiring psychiatric therapy. Patient age ranged from 27 to 76 years $(\mathrm{M}=46.72$, sd=9.318). The majority of patients were right-handed $(\mathrm{n}=82)$ and only three patients were lefthanded. Average education was 12 years (M =11.76; sd=2.727); most patients had completed secondary education (high school level), 13\% had only elementary school, $22 \%$ had higher education, while $5 \%$ had no school.

As for the number of aneurysms, 77 patients had only one aneurysm and 15 patients had multiple aneurysms; 83 patients had only one surgery, five patients were submitted to two surgical procedures, and three patients had more than two surgeries. Detailed information on the number of surgeries for aneurysm is presented in Table 1 . The majority of patients had aneurysms in either left $(n=44)$ or right $(n=32)$ brain hemisphere, while 15 patients had aneurysms in both hemispheres. The aneurysms were usually located in one of the 5 arteries (anterior communicating artery aneurysm, ACoA; anterior artery aneurysm, ACA; medial artery aneurysm, $\mathrm{ACM}$; internal carotid artery aneurysm, ACI; and basilar artery aneurysm, AB), some were located in more than one artery or even in those that were not specifically mentioned. These data are presented in Table 2 .

\section{Instruments}

The following types of memory were investigated: numerical memory or memory of numbers, working memory or repeating numbers backwards, verbal-mechanical memory or memory of a list of words, verballogical memory or memory of stories, and visual memory or memory of pictures. These types of memory were assessed by the following tests: Wechsler Memory Scale (WMS), Auditory-Verbal Learning Test (AVLT) and Rey Complex Figure Test (RCFT).

\section{a) Wechsler Memory Scale (WMS)}

Numerical memory or memory of numbers was assessed by numerical memory subtest that is part of the WMS, and it consists of forward and backward repeating of numbers. Forward repeating of numbers is a measure of numerical memory, while repeating the numbers backwards is a measure of working memory. Maximum possible score in forward memorizing numbers is 9 , and 8 for backward memorizing. Total score equals the sum of forward and backward number memorizing scores. In our study, the numerical and working memory results were presented and analyzed separately.

Verbal-logical memory is measured by the WMS subtest of logical recalling. The subtest contains two short stories and a defined number of points (score) is given to each separate unit of the story. A maximum number of points is 20 . In our study, only one story was read and patients were asked to retell the story immediately upon its reading (short-term memory) and at the end of neuropsychological assessment (long-term memory).

b) Verbal-mechanical memory was assessed by the Auditory-Verbal Learning Test (AVLT), meant for evaluation of short-term memory, learning curve, learning and memorizing strategies, retroactive and proactive interference, and long-term memory. The 
test contains two lists of 15 words. The study participant is verbally presented list A for five times and after each presentation he/she is asked to repeat all the words he/she can remember. The results obtained after reading the fifth list indicates memory capacity, and the results from 1 to 5 repetitions show the learning curve. The sixth and seventh repetitions are the measure of short-term and long-term memory, respectively. The result for each word reproduction is total number of repeated words in a given trial period.

c) Visual memory, or memorizing pictures is measured by the Rey Complex Figure Test (RCFT). The RCFT is neuropsychological assessment in which the subjects are asked to reproduce a complicated line drawing, first by copying it freehand (recognition), and then drawing from memory (recall). Many different cognitive abilities are needed for correct performance, and the test therefore permits evaluation of different functions such as attention, planning, working memory, but mostly visuospatial abilities and visual memory, i.e. visual short-term memory (immediate recall) and visual long-term memory (delayed recall). The RCFT contains 4 tasks: copying, short- and long-term memorizing, and recognition. Of the test results obtained, only data on short-term and long-term memory were taken into consideration, i.e. results for the $2^{\text {nd }}$ and $3^{\text {rd }}$ task according to the number of points achieved.

\section{Procedure}

The study was conducted at Department of Neurosurgery, Zagreb University Hospital Centre, during the 1998-2012 period. The first neuropsychological testing took place within 1-11 months following surgery, and the second one within 12-48 months after surgery. Neuropsychological assessment was carried out by an experienced psychologist and included clinical interview and neuropsychological tests described above.

\section{Statistics}

Windows package for statistics was used on data analysis. Descriptive statistics was applied in general and t-test for dependent samples for statistical significance of difference of the results obtained in the two testing periods. The normality of distribution was tested by Kolmogorov-Smirnov test and normal distribution was obtained for all variables.

\section{Results}

The first objective of the study was to define whether there were deficits in numerical, working, verbalmechanical (capacity, learning curve, short- and longterm), verbal-logical (short- and long-term) and visual memory (short- and long-term) in a time span of up to 11 months and 12-48 months following surgery for brain artery aneurysm. Study results are shown in Table 3.

A result of 6 repeated numbers forwardly is considered to be within normal achievement, whereas a result of 5 repeated numbers is accepted as being on the lower border of normal according to Lezak ${ }^{20}$. During the $1^{\text {st }}$ testing period, the patients achieved a mean result of 5.89 numbers $\left(\mathrm{M}_{1}=5.89 ; \mathrm{sd}_{1}=1.080\right)$, whereas on the $2^{\text {nd }}$ testing the mean result was $5.87 \quad\left(\mathrm{M}_{2}=5.87\right.$; $\left.\operatorname{sd}_{2}=1.132\right)$. These results revealed that in this test there were no significant deviations from what was expected. Regarding repetition of numbers backward, the result was 4 in both testing periods $\left(\mathrm{M}_{1}=4.01 ; \mathrm{sd}_{1}=0.957\right.$; $\mathrm{M}_{2}=4.15 ; \mathrm{sd}_{2}=0.982$ ), which is considered as a lower border of normal for this test. Gross result of 4 or 5 is generally considered normal for healthy population according to Lezak ${ }^{20}$, particularly in view of the average age of our study participants of 47 years. Based on the results shown in Table 3 concerning numerical and working memory in our study participants, it may be concluded that there was no significant deficit in either numerical or working memory in both testing periods. As for the verbal-mechanical memory test in the first trial of reproducing, which indicates initial learning, healthy individuals remember a mean of 6.3 to 7.8 words ${ }^{20}$. The results shown in Table 3 indicate that the group of patients in the first testing period achieved a score belonging to the lower border of average $\left(M_{1}=6.34 ; \mathrm{sd}_{1}=1.842\right)$, whereas on second testing they scored lower than average $\left(\mathrm{M}_{2}=5.77 ; \mathrm{sd}_{2}=1.132\right)$. Each subsequent repetition, i.e. learning, should result in a greater number of reproduced words, and this is clearly visible in the results of patients who on the $1^{\text {st }}$ and $2^{\text {nd }}$ testing showed an increased number of reproduced words from first to fifth trial (Table 3); in the fifth trial, it also indicates the capacity of memory. Figure 1 presents comparison of learning curves on the $1^{\text {st }}$ and $2^{\text {nd }}$ testing and the expected results according to norms. It is seen that our patients had poorer scores than expected at each subsequent repetition trial, except for 
Table 3. Descriptive statistics for numerical, working, verbal-mechanical, verbal-logical and visual memory following surgery for brain artery aneurysm on $1^{\text {st }}$ and $2^{\text {nd }}$ testing

\begin{tabular}{|l|l|l|l|l|l|l|l|}
\hline & & \multicolumn{3}{|c|}{$1^{\text {st }}$ testing } & \multicolumn{3}{|c|}{$2^{\text {nd }}$ testing } \\
\hline Type of memory & & $\mathrm{n}$ & $\mathrm{M}$ & $\mathrm{SD}$ & $\mathrm{n}$ & $\mathrm{M}$ & $\mathrm{SD}$ \\
\hline Numerical memory & & 85 & 5.89 & 1.080 & 85 & 5.87 & 1.132 \\
\hline Working memory & & 85 & 4.01 & 0.957 & 85 & 4.15 & 0.982 \\
\hline Verbal-mechanical memory & AVLT1 & 44 & 6.34 & 1.842 & 44 & 5.77 & 1.553 \\
& AVLT2 & 44 & 7.98 & 2.267 & 44 & 8.11 & 2.254 \\
& AVLT3 & 44 & 9.23 & 2.458 & 44 & 9.05 & 2.477 \\
& AVLT4 & 44 & 10.09 & 2.361 & 44 & 10.30 & 2.792 \\
& AVLT5 & 44 & 10.45 & 3.038 & 44 & 10.45 & 2.984 \\
& AVLT6 & 44 & 7.52 & 4.003 & 44 & 8.05 & 4.176 \\
& AVLT7 & 44 & 7.00 & 4.477 & 44 & 7.82 & 4.282 \\
\hline Verbal-logical memory & Short-term & 89 & 8.506 & 3.392 & 89 & 9.067 & 3.233 \\
& Long-term & 70 & 7.00 & 4.107 & 70 & 7.586 & 3.824 \\
\hline Visual memory & Short-term & 56 & 17.83 & 7.175 & 56 & 21.09 & 7.976 \\
& Long-term & 56 & 15.99 & 7.086 & 56 & 19.19 & 7.797 \\
\hline
\end{tabular}

$1^{\text {st }}$ testing = time span up to 11 months following surgery; $2^{\text {nd }}$ testing = time span from 12 to 48 months following surgery; AVLT = Audio Verbal Learning Test

the $1^{\text {st }}$ testing period during the first repetition trial. A positive fact is that the study participants managed to learn (memorize) 5 items from first to fifth repetition, which means that learning still existed but with a deficient capacity.

In the fifth trial of reproducing, healthy individuals reproduce correctly 12 to 14 words on average ${ }^{20}$. Our study participants had almost the same result on the $1^{\text {st }}$ and $2^{\text {nd }}$ testings, i.e. they had 11 repeated words at a relatively great standard deviation $\left(\mathrm{M}_{1,2}=10.45\right.$; $\left.\mathrm{sd}_{1}=3.038, \mathrm{sd}_{2}=2.984\right)$; such a result led to a conclusion that there was a mild deficit in the capacity of memory.

In the sixth trial, healthy individuals usually repeat two words less than in the fifth trial, i.e. they reproduce 10 to 12 words, which is indicative of the capacity of short-term verbal-mechanical memory. Our study participants reproduced a mean of 7.52 words in the $1^{\text {st }}$ testing $\left(\mathrm{M}_{1}=7.52 ; \mathrm{sd}_{1}=4.003\right)$, i.e. they forgot 3 of 11 memorized words on average, which indicates a deficit of short-term memory; long-term repetition ranged up to 7 words $\left(\mathrm{M}_{1}=7.00 ; \mathrm{sd}_{1}=4.477\right)$, indicating deficits in long-term memory. In the $2^{\text {nd }}$ testing, short-term memorizing reached 8.05 words $\left(\mathrm{M}_{2}=8.05 ; \mathrm{sd}_{2}=4.176\right)$, meaning that they forgot a mean of 2.5 words, which is still within the normal curve of forgetting. As for long-term repetition, our patients reproduced a mean

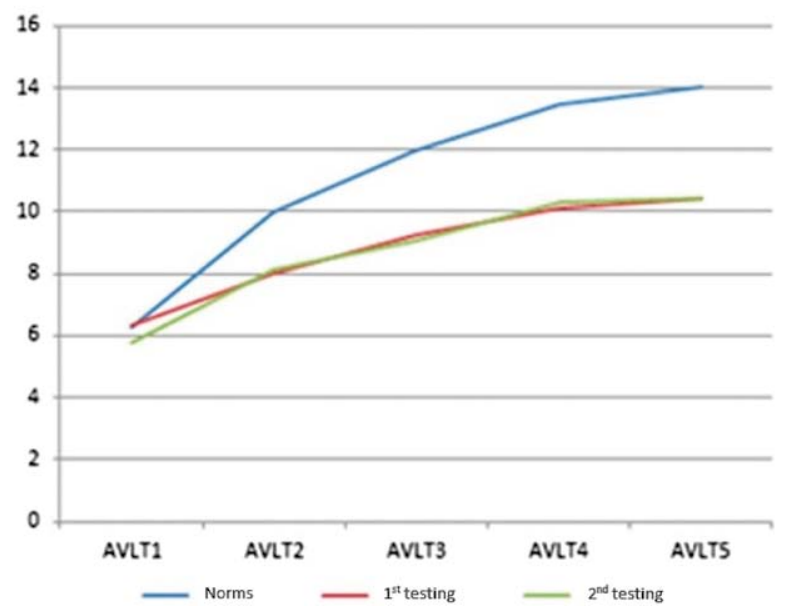

Fig. 1. Learning curve of patients following artery aneurysm surgery on $1^{\text {st }}$ and $2^{\text {nd }}$ testing compared with expectations according to norms.

AVLT $=$ Audio Verbal Learning Test

of 7.82 words in the $2^{\text {nd }}$ testing period $\left(\mathrm{M}_{2}=7.82\right.$; $\mathrm{sd}_{2}=4.282$ ), which is within wider borders of the normal curve since forgetting 3 and more words is considered pathological, i.e. indicating long-term memory deficits (namely, of the 10.45 memorized words, our patients repeated a mean of 7.82 words). 
Table 4. Recovery of memory with time (reduction of deficit)

\begin{tabular}{|c|c|c|c|c|}
\hline \multicolumn{2}{|l|}{ Type of memory } & $\mathrm{t}$ & $\mathrm{df}$ & $\mathrm{p}$ \\
\hline \multicolumn{2}{|l|}{ Numerical memory } & 0.253 & 84 & 0.801 \\
\hline \multicolumn{2}{|l|}{ Working memory } & -1.590 & 84 & 0.116 \\
\hline \multirow{7}{*}{$\begin{array}{l}\text { Verbal-mechanical } \\
\text { memory }\end{array}$} & AVLT1 & 2.307 & 43 & $0.026^{*}$ \\
\hline & AVLT2 & -0.526 & 43 & 0.602 \\
\hline & AVLT3 & 0.759 & 43 & 0.452 \\
\hline & AVLT4 & -0.692 & 43 & 0.492 \\
\hline & AVLT5 & 0.000 & 43 & 1.000 \\
\hline & AVLT6 & -1.319 & 43 & 0.194 \\
\hline & AVLT7 & -2.196 & 43 & $0.034^{*}$ \\
\hline \multirow{2}{*}{$\begin{array}{l}\text { Verbal-logical } \\
\text { memory }\end{array}$} & Short-term & -1.718 & 88 & 0.090 \\
\hline & Long-term & -1.522 & 69 & 0.132 \\
\hline \multirow[t]{2}{*}{ Visual memory } & Short-term & -4.995 & 55 & $0.000^{*}$ \\
\hline & Long-term & -4.636 & 55 & $0.000^{*}$ \\
\hline
\end{tabular}

* $\mathrm{p}<0.05 ; \mathrm{AVLT}=$ Audio Verbal Learning Test

Based on these results, it can be concluded that verbal-mechanical memory suffered from deficits in terms of diminished capacity and deficits of short- and long-term memory in the $1^{\text {st }}$ testing period. In the $2^{\text {nd }}$ testing period, the capacity deficits were present and so were poor results for every point of the learning curve; however, the results for short- and long-term memory ranged within wider normal limits.

Verbal-logical memory showed deficits in both testing periods. The minimal number of memorized words for healthy population, i.e. the number that would not be designated as memory deficit, is 10 (50\%). In the first testing period, our patients memorized a mean of $\mathrm{M}_{1 \mathrm{k}}=8.506$ words at $\mathrm{sd}_{1 \mathrm{k}}=3.392$ in short-term memorizing, and $\mathrm{M}_{1 \mathrm{~d}}=7.00$ items at $\mathrm{sd}_{1 \mathrm{~d}}=4.107$ in long-term memorizing. In the $2^{\text {nd }}$ testing, short-term memorizing reached a mean of $\mathrm{M}_{2 \mathrm{k}}=9.067$ words at $\mathrm{sd}_{2 \mathrm{k}}=3.233$, while the long-term one reached a mean of $\mathrm{M}_{2 \mathrm{~d}}=7.586$ words at $\mathrm{sd}_{2 \mathrm{~d}}=3.824$. These results showed that there were deficits of both short- and long-term verbal-mechanical memory in both testing intervals, although the deficits were less pronounced in second testing.

The results of visual short- and long-term memory in the $1^{\text {st }}$ and $2^{\text {nd }}$ testing periods are presented in Table 3. The expected results in view of achievements of healthy adults for tasks of immediate recall reach a mean of 23.67 points $(\mathrm{Mk}=23.67$; $\mathrm{sdk}=4.25)$, and for the task of postponed recall, or long-term memory, they reach 23.86 points $(\mathrm{Md}=23.86$; sd=4.58), according to Meyers and Meyers ${ }^{21}$. According to Lezak ${ }^{20}$, healthy adults are expected to achieve 22 points on average. In the first testing period, our study participants achieved a mean of 17.83 points $\left(\mathrm{M}_{1 \mathrm{k}}=17.83\right.$; $\left.\mathrm{sd}_{1 \mathrm{k}}=7.157\right)$ for tasks of immediate recall, while for tasks of long-term recall they achieved 15.99 points $\left(\mathrm{M}_{1 \mathrm{~d}}=15.99 ; \mathrm{sd}_{1 \mathrm{~d}}=7.086\right)$. In the $2^{\text {nd }}$ testing period, the result for tasks of immediate recall was a mean of 21.09 points $\left(\mathrm{M}_{2 \mathrm{k}}=21.09 ; \mathrm{sd}_{2 \mathrm{k}}=7.976\right)$, and 19.99 points $\left(\mathrm{M}_{2 \mathrm{~d}}=19.99 ; \mathrm{sd}_{2 \mathrm{~d}}=7.797\right)$ for tasks of postponed recalling. Comparison of these results and the expected mean revealed that our study participants had visual short- and long-term memory deficits in both testing periods, although the deficits shown in the $2^{\text {nd }}$ testing period were less pronounced.

Another issue addressed in our study was to find out whether recovery of memory functions (diminishing of deficits) takes place with time, particularly on the basis of comparison of the results of neuropsychological evaluation performed in two time periods $\left(1^{\text {st }}\right.$ and $2^{\text {nd }}$ testing). T-test was used for dependent samples since we were dealing with data on dependent variables during a long-term study. These results are shown in Table 4.

No statistically significant difference was found for tests of numerical and working memory.

Regarding the results of verbal-mechanical memory, a statistically significant difference was found between the $1^{\text {st }}$ and $2^{\text {nd }}$ testing in first and seventh trial of word reproduction. In the first trial of reproducing words, which is an indicator of initial learning, a statistically significant change occurred between the $1^{\text {st }}$ and $2^{\text {nd }}$ testing $\left(t_{1}(43)=2.307 ; p<0.05\right)$, specifically in terms of increased deficit, i.e. in the $2^{\text {nd }}$ testing, study participants reproduced a lower number of words than in the $1^{\text {st }}$ testing $\left(\mathrm{M}_{1,1}=6.34 ; \mathrm{sd}_{1,1}=1.842 ; \mathrm{M}_{1,2}=5.77 ; \mathrm{sd}_{1,2}=\right.$ 1.533). Also, as previously stated, a statistically significant change occurred in the seventh trial of word reproducing $\left(\mathrm{t}_{7}(43)=-2.196 ; \mathrm{p}<0.05\right)$, in terms of recovery of long-term memory, i.e. study participants reproduced significantly more words in the second testing than in the first one. For the second, third, fourth, fifth and sixth trials of word reproducing, there were no statistically significant differences. There was no statistically significant recovery of verbal-logical short-term $\left(t_{k}(88)=-1.718 ; p>0.05\right)$ and long-term memory 
$\left(t_{d}(69)=-1.522 ; p>0.05\right)$ either. However, statistically significant recovery was observed in the function of both short- and long-term visual memory. In visual short-term memory, a statistically significant change occurred $(t(55)=-4.995 ; \mathrm{p}<0.05)$ in terms of recovery, i.e. the participants achieved better results in the $2^{\text {nd }}$ than in the $1^{\text {st }}$ testing. Still, visual short-term memory was shown to be slightly deficient in the $2^{\text {nd }}$ testing $\left(\mathrm{M}_{1 \mathrm{k}}=17.83 ; \mathrm{sd}_{1 \mathrm{k}}=7.157 ; \mathrm{M}_{2 \mathrm{k}}=21.09 ; \mathrm{sd}_{2 \mathrm{k}}=7.976\right)$. As for visual long-term memory, statistically significant recovery was confirmed $(t(55)=-4.636 ; \mathrm{p}<0.05)$, i.e. the results were better in the $2^{\text {nd }}$ testing, although visual long-term memory remained deficient in the $2^{\text {nd }}$ testing $\left(\mathrm{M}_{1 \mathrm{~d}}=15.99 ; \mathrm{sd}_{1 \mathrm{~d}}=7.086 ; \mathrm{M}_{2 \mathrm{~d}}=19.99 ; \mathrm{sd}_{2 \mathrm{~d}}=7.797\right)$.

\section{Discussion}

Analysis of the results obtained in our study showed that after SAH and surgery for cerebral aneurysm, the patients suffered from deficits in some but not all types of memory. No deficits were found in numerical and working memory either in the first or second testing since the patients achieved average results. Furthermore, the results showed deficits in all aspects of verbal-mechanical memory in the $1^{\text {st }}$ testing, whereas in the $2^{\text {nd }}$ testing, recovery of short- and long-term memory was observed; the results obtained were within wider limits of average, i.e. forgetting was no longer present to a significant degree. Short- and long-term verbal-logical memory showed mild deficits in the $1^{\text {st }}$ and $2^{\text {nd }}$ testing. The results also showed deficits in visual short- and long-term memory.

Our study results are similar to those obtained in many other studies, indicating that memory deficit in patients after SAH and surgery for brain artery aneurysm presents the most common problem not only to patients but to their family members as well. Laiacona et al..$^{22}$ found significant memory deficits, short-term memory in particular, in 43 patients after surgical treatment of ACoA aneurysm. Ogden et al. ${ }^{23}$ state that even $41 \%$ of patients complain of memory problems following cerebral aneurysm surgery, while Fauvage et al. ${ }^{24}$ report on $65 \%$ of patients with cognitive deficits, the most frequent ones among which are memory deficits. Rinkel and Algra ${ }^{25}$ report that patients most often complain of having problems with short-term memory. Bendel et al. ${ }^{26}$ state that $54 \%$ of patients show cognitive deficit after SAH and aneurysm surgery.
Berry et al. ${ }^{27}$ included 48 patients in their study and found that SAH itself was an essential and significant factor in later development of neuropsychological deficiencies. Bottger et al. ${ }^{28}$ studied 30 patients after $\mathrm{SAH}$ and $\mathrm{ACoA}$ aneurysm surgery, and report on three patient groups: patients with memory deficit as a dominant one; predominant deficit of executive functions; and predominant deficit of attention functions. Otawara et al. ${ }^{29}$ carried out a similar study on $117 \mathrm{pa}-$ tients surgically treated for aneurysmal SAH, and their results showed cognitive function deficit in 73 (62.4\%) patients.

Studies of numerical memory indicate that this type of memory is also deficient in patients surgically treated for aneurysm of cerebral artery. Pačić-Turk ${ }^{30}$ studied numerical memory functions in the period of 6-12 months following surgery. Numerical memory deficits were present in both testing periods. Fertl et al. ${ }^{31}$ also studied numerical memory and found that deficits of numerical memory existed in $25 \%$ of patients; problems with reverse repeating of numbers were more expressed (working memory) than with forward repetition (short-term memory). However, these results are not in accordance with our study results, since our patients achieved average results in both testing periods.

Many authors have on numerous different occasions studied verbal-mechanical memory of patients surgically treated for brain artery aneurysm. Germano et al. ${ }^{32}$ report no statistically significant difference in the results for short-term versus long-term verbal-mechanical memory between patients surgically treated for brain artery aneurysm and healthy controls. Opposed to that, Simard et al. ${ }^{14}$ state that a significant number of patients show deficits in tests of verbalmechanical short- and long-term memory. Stefanova et $a .^{33}$ studied patients after ACoA aneurysm surgery and found that they had deficits of verbal-mechanical short- and long-term memory following surgical procedures, which indicates that difficulties were also present in episodic memory when learning word lists.

In the study carried out by Germano et $a l^{32}$, no deficits of verbal-logical memory were found after surgical treatment of brain artery aneurysm, i.e. no statistically significant difference was found between the results obtained by patients and healthy controls. The same results were obtained by Kubo et al. $^{34}$, stating that deficits of verbal-logical short- and long-term memo- 
ry were found in none of their study patients. However, our study results indicated that there was deficit in short- and long-term verbal-logical memory in both testing periods, which is opposed to the above studies. Yet, Hütter et al..$^{35}$ obtained similar results to those recorded in our study; they studied 28 patients at 1 to 13 days of early aneurysm surgery applying a relatively great number of neuropsychological tests confirming the existence of short- and long-term verbal-logical memory deficits. Fontanella et al. ${ }^{11}$ found that verballogical memory in patients surgically treated for brain artery aneurysm was statistically significantly worse than in healthy controls. Simard et al. ${ }^{14}$ also point out deficits in short- and long-term verbal-mechanical memory in patients surgically treated for brain artery aneurysm.

Similar to our study results of visual memory deficits, Cheng et al. ${ }^{36}$ report on patients having problems with visual reproduction, which might account for their poor results. Santiago-Ramajo et al. ${ }^{37}$ found deficits of visual memory in both Rey and Benton tests. Simard et al. ${ }^{14}$, like Diamond et al. ${ }^{38}$, also report on the same pattern, i.e. that both short- and long-term memory is deficient in these patients.

Our study results indicated statistically significant recovery to have occurred in verbal-mechanical longterm memory and visual short- and long-term memory, whereas no statistically significant recovery was observed with the passage of time for other types of memory investigated as part of our study. Numerical and working memory showed no deficits in the $1^{\text {st }}$ and $2^{\text {nd }}$ testing period, although statistically significant recovery in terms of better functioning was not found. In verbal-mechanical memory, no significant recovery of short-term memory occurred, although the results obtained in the $2^{\text {nd }}$ testing ranged within wider limits of normal and patients no longer presented significant deficits. Another statistically significant change was observed; namely, in the first trial of word reproduction during the second testing period, deficit was increased, i.e. at the beginning of learning during the second testing period, study participants reproduced a smaller number of words than in the $1^{\text {st }}$ testing.

Recovery after surgical treatment of aneurysm is a dynamic process. Hypothetical curve of recovery has not yet been established. Despite general opinion that after 6 months of the surgery, final outcome of recovery can be seen, there is evidence that with late rehabilitation, even many years after cerebral lesion, recov- ery can still be quite successful ${ }^{39}$. Many studies were dealing with analysis of memory functions with the passage of time. Ljunggren et al. ${ }^{10}$ report that despite satisfactory neurological recovery, patients still complain of cognitive and emotional functioning. Among 118 patients with satisfactory neurological recovery, a sample of 40 patients was selected and they were tested in a time period of 14 months to 7 years following surgery. Cognitive deficits were found, ranging from mild to more severe ones. Ogden et al..$^{23}$ found that in a time span of 4 to 7 years following $\mathrm{SAH}$ and surgery, $41 \%$ of patients still had memory difficulties. Czepko et al. ${ }^{40}$ found cognitive deficits in a period longer than 5 years after surgical treatment of $\mathrm{ACoA}$ aneurysm in 43 patients, related mostly to short-term memory, psycho-motor speed and concentration. King et al. ${ }^{41}$ studied cognitive functions in patients following aneurysm surgery and again at 12 months of initial testing. They report on negative effects of SAH on cognitive functioning. The study carried out by Pačić-Turk ${ }^{30}$ in 1996 included 32 patients, and the following functions were examined: general intellectual functioning, thinking, mnemonic functions, visual perception, visual-perceptual organization, perceptive-motor speed, and speech. The results showed that in 6-month period, significant deficits of all examined cognitive functions including memory still existed, and that there was a tendency toward spontaneous recovery with the passage of time, although recovery was statistically significant only for some functions. Recovery of different functions varied significantly, which was also observed in the present study results.

Ohue et al. ${ }^{13}$ found deficits of verbal memory in patients surgically treated for brain artery aneurysm. The problem of verbal memory recovery was addressed by Haug et al. ${ }^{12}$; their study results showed that verbal memory recovered 6 months after surgery, which is not in accordance with our study results. Cheng et al. ${ }^{36}$ report that patients have problems with verbal fluency after surgery for brain artery aneurysm, which could be the reason why they reproduce a smaller number of words than supposedly memorized. Furthermore, deficits in verbal-mechanical and verbal-logical memory could also be explained by aneurysm location in brain hemispheres. As shown in Table 1, in our patients, most aneurysms were located in the left cerebral hemisphere, the one that is dominant for verbal functions. All of the above studies showed evidence for negative 
effects of brain aneurysms on memory functions; hence, when more aneurysms are located in the left cerebral hemisphere, it is logical that they will negatively affect verbal functions and therefore also the functions of verbal memory.

Another possible explanation of poorer recovery of memory functions with time than expected could be found in the study carried out by Pačić-Turk et al. ${ }^{42}$, who investigated personality changes in patients following surgery for brain artery aneurysm. In the second period, the majority of patients experienced more pronounced reactive changes in terms of increased anxiety, hypersensitivity, paranoid and aggressive tendencies, all of which significantly influence the functions of attention, concentration and memory ${ }^{20}$. The fact is that many patients suffering from brain lesions experience emotional disorders that affect their everyday living, anxiety and depression being among the most common ones. Anxiety leads to distraction and concentration difficulties, while depression results in the lack of interest and decreased arousal. In combination with mood changes, they all affect performance in many neuropsychological tests, including memory tests $^{32}$.

Our study obviously had its limitations. The first to note was a small sample and unequal proportion of age groups and male and female study participants, as well as unequal number of aneurysms with regard to their location in the left or right cerebral hemisphere. It is also possible that memory deficits and recovery were affected by factors that were not taken into consideration but could have affected patient ability to solve test items and their cognitive function in general, such as type of surgery, presence and size of SAH, time span from surgery to neuropsychological testing, compliance with physician's instructions, cognitive rehabilitation, family support, etc.

In conclusion, in the first testing carried out up to 11 months after surgical treatment of cerebral artery aneurysm, the following memory deficits were found: (1) verbal-mechanical (capacity, learning curve, shortand long-term); (2) verbal-logical (short- and longterm); and (3) visual (short- and long-term). Regarding the measurements of numerical and working memory, our study participants achieved average results. In the second testing carried out 12 to 48 months following surgery, deficits of verbal-logical and visual memory were still present. In the second testing peri- od, deficits of capacity and learning curve in the test of verbal-mechanical learning and memorizing still persisted, but the results for short- and long-term memory were found within wider ranges of normal. Our study participants continued to achieve average results for the parameters of numerical and working memory. With regard to the issue of memory recovery with the passage of time, statistically significant recovery was found in visual short- and long-term memory; study participants achieved much better results during the second testing period, particularly in terms of having only mild deficits. Long-term verbal-mechanical memory also improved with the achieved results ranging within wider limits of normal.

\section{References}

1. Grbavac Ž. Neurologija. Zagreb: Sagena, 1992. (in Croatian)

2. Phillips L, Whisnant J, O'Fallon M, Sundt, T. The unchanging pattern of subarachnoid hemorrhage in a community. J Neurol. 1980;30:1034-40.

DOI: https://doi.org/10.1212/WNL.30.10.1034

3. Gavranić A, Šimić H, Škoro I, Stanković B, Rotim K, Kolić Z. Subarahnoidalno krvarenje. Medicina Fluminensis. 2011;47: 143-56. (in Croatian)

4. Halligan PW, Kischka U, Marshall JC. Handbook of Clinical Neuropsychology. New York: Oxford University Press, 2003. DOI:10.1093/acprof:oso/9780199234110.001.0001

5. Pačić-Turk Lj, Kostović-Srzentić M. Klinička neuropsihologija. Zagreb: Zdravstveno veleučilište, 2011. (in Croatian)

6. Galić S. Neuropsihologijska procjena. Jastrebarsko: Naklada Slap, 2002. (in Croatian)

7. Stenhouse LM, Knight RG, Longmore BE, Bishara SN. Long-term cognitive deficits in patients after surgery on aneurysms of the anterior communicating artery. J Neurol Neurosurg Psychiatry. 1991;54:909-14.DOI 10.1136/jnnp.54.10.909

8. Okawa M, Maeda S, Nukui H, Kawafuchi J. Psychiatric symptoms in ruptured anterior communicating aneurysms: social prognosis. Acta Psychiatr Scand. 1980;61:306-12. https://doi. org/10.1111/j.1600-0447.1980.tb00583.x

9. DeLuca J, Diamond BJ. Anterior communicating artery aneurysm: a review of neuroanatomical and neuropsychological sequelae. J Clin Exp Neuropsychol. 1995;17:100-21. https://doi. org/10.1080/13803399508406586

10. Ljunggren B, Sonesson B, Saveland H, Brandt L. Cognitive impairment and adjustment in patients without neurologic deficits after aneurysmal SAH and early operation. J Neurosurg. 1985;62:673-9. DOI:10.3171/jns.1985.62.5.0673

11. Fontanella M, Perozzo P, Ursone R, Garbossa D, Bergui M. Neuropsychological assessment after microsurgical clipping or endovascular treatment for anterior communicating artery 
aneurysm. Acta Neurochir. 2003;145:867-72. DOI:10.1007/ s00701-003-0111-5

12. Haug T, Sorteberg A, Lindegaard KF, Lundar T, Finset, A. Cognitive outcome after aneurysmal subarachnoid hemorrhage: time course of recovery and relationship to clinical, radiological, and management parameters. Neurosurgery. 2007; 60:649-57. DOI:10.1227/01.NEU.0000255414.70807.A0

13. Ohue S, Oka Y, Kumon Y, Ohta S, Sakaki S, Hatakeyama T, Shiraishi T, Takeda S, Ohnishi T. Importance of neuropsychological evaluation after surgery in patients with unruptured cerebral aneurysms. Surg Neurol. 2003;59:269-76.

14. Simard S, Rouleau I, Brosseau J, Laframboise M, Bojanowsky M. Impact of executive dysfunctions on episodic memory abilities in patients with ruptured aneurysm of the anterior communicating artery. Brain Cognition. 2003;53:354-8.

15. Tooth CL, Tindale WB, Hadjivassiliou M, Romanovski CA, Hunt E, Pantke R, Sagar HJ, Mayes AR. Subcortical hypoperfusion following surgery for aneurysmal subarachnoid haemorrhage: implications for cognitive performance. Behav Neurol. 2000;12:39-51.

16. Ørbo M, Waterloo K, Egge A, Isaksen J, Ingebrigtsen T, Romner B. Predictors for cognitive impairment one year after surgery for aneurysmal subarachnoid hemorrhage. J Neurol. 2008;255:1770-6. doi: 10.1007/s00415-008-0047-z.

17. Al-Khindi T, MacDonald RL, Schweizer TA. Cognitive and functional outcome after aneurysmal subarachnoid hemorrhage. Stroke. 2010;41:519-36. DOI:10.1161/STROKEAHA. 110.581975

18. Bernadini GL, Mayer SA. Subarachnoid hemorrhage: clinical presentation and neuropsychological outcome. Medical Update for Psychiatrists. 1995;3:71-6.

19. Otawara Y, Ogasawara K, Ogawa A, Yamadate K. Cognitive function before and after surgery in patients with unruptured intracranial aneurysm. Stroke. 2005;36:142-3. https://doi.org/ 10.1161/01.STR.0000149925.36914.4e

20. Lezak MD. Neuropsychological Assessment. New York: Oxford University Press, 1995.

21. Meyers JE, Meyers KR. Rey Complex Figure Test and Recognition Trial. Odessa, FL, USA: Psychological Assessment Resources, 1995.

22. Laiacona M, DeSantis A, Barabarotto R, Basso A, Spagnoli D, Capitani E. Neuropsychological follow-up of patients operated for aneurysms of anterior communicating artery. Cortex. 1989; 25;267-73.

23. Ogden JA, Utley T, Mee EW. Neurological and psychosocial outcome 4 to 7 years after subarachnoid hemorrhage. Neurosurgery. 1997;41:25-34.

24. Fauvage B, Canet C, Coppo F, Jacquot C, Payen, JF. Long-term outcome of patients after aneurysmal SAH. Ann Fr Anesth Reanim. 2007;26:959-64.

25. Rinkel GJE, Algra A. Long-term outcomes of patients with aneurysmal subarachnoid haemorrhage. Neurology. 2011;10: 349-56. DOI:10.1016/S1474-4422(11)70017-5
26. Bendel P, Koivisto T, Niskanen E, Könönen M, Äikiä M, Hanninen T, Koskenkorva P, Vanninen R. Brain atrophy and neuropsychological outcome after treatment of ruptured anterior cerebral artery aneurysms: a voxet-based morphometric study. Neuroradiology. 2009;51:711-22. DOI:10.1007/ s00234-009-0552-5

27. Berry E, Jones RA, West CG, Brown JD. Outcome of subarachnoid hemorrhage. An analysis of surgical variables, cognitive and emotional sequelae related to SPECT scanning. Br J Neurosurg. 1999;11:378-87. https://doi.org/10.1080/ 02688699745853

28. Bottger S, Prosiegel M, Steiger HJ, Yassouridis A. Neurobehavioral disturbances, rehabilitation outcome and lesion site in patients after rupture and repair of anterior communicating artery aneurysm. J Neurol Neurosurg Psychiatry. 1998;65: 93-102. DOI:10.1136/jnnp.65.1.93

29. Otawara Y, Ogasawara K, Kubo Y, Kashimura H, Ogawa A, Yamadate K. Comparison of postoperative cognitive function in patients undergoing surgery for ruptured and unruptured intracranial aneurysm. Surg Neurol. 2009;72:592-5. DOI: 10.1016/j.surneu.2009.06.016

30. Pačić-Turk Lj. Neuropsihologijski deficiti i promjene ličnosti nakon operacije aneurizme moždanih arterija. MS thesis. Zagreb: School of Medicine, University of Zagreb, 1996. (in Croatian)

31. Fertl E, Killer M, Eder H, Linzmayer L, Richling B, Au E. Long-term functional effects of aneurysmal subarachnoid haemorrhage with special emphasis on the patient's view. Acta Neurochirurg. 1999;141:571-7.

32. Germano A, Caruso G, Caffo M, Cacciola F, Belvedere M, Tisano A, Raffaele M, Tomasello F. Does subarachnoid blood extravasation per se induce long-term neuropsychological and cognitive alterations? Acta Neurochirurg. 1998;140:805-12.

33. Stefanova ED, Kostić VS, Ziropadja Lj, Marković M, Očić G. Serial position learning effects in patients with aneurysms of anterior communicating artery. J Clin Exp Neuropsychol. 2002;24:687-94.

34. Kubo Y, Ogasawara K, Kashimura H, Otawara Y, Kakino S, Sugawara A, Ogawa A. Cognitive function and anxiety before and after surgery for asymptomatic unruptured intracranial aneurysms in elderly patients. World Neurosurg. 2010;73: 350-3. DOI:10.1016/j.wneu.2010.01.001

35. Hütter BO, Gilsbach JM, Kreitschmann I. Quality of life and cognitive deficits after subarachnoid haemorrhage. Br J Neurosurg. 1995;9:465-75.

36. Cheng H, Shi J, Zhou M. Cognitive assessment in Chinese patients with aneurysmal subarachnoid hemorrhage. Behav Neurol. 2006;17:117-20.

37. Santiago-Ramajo S, Katati MJ, Perez-Garcia M, Coin-Meijas MA,Vilar-Lopez R, Caracuel-Romero A, Arjona-Moron V. Neuropsychological evaluation of the treatments applied to intracranial aneurysms in a Spanish sample. J Clin Exp Neuropsychol. 2007;29:634-41. DOI: 10.1080/13803390600879024 
38. Diamond BJ, DeLuca J, Kelley SM. Memory and executive functions in amnesic and non-amnesic patients with aneurysms of the anterior communicating artery. Brain. 1997; 120:1015-25. DOI:10.1093/brain/120.6.1015

39. Beristain X, Gaviria M, Dujovny M, Abd El-Bary TH, Stark JL, Ausman JI. Evaluation of outcome after intracranial aneurysm surgery: the neuropsychiatric approach. Surg Neurol. $1996 ; 45: 422-9$.

40. Czepko R, Orlowiejska M, Danilewicz B. Neuropsychological disorders after subarachnoid hemorrhage and surgery in ante- rior communicating artery brain aneurysms. Przegl Lek. 1999; $56: 720-2$.

41. King JT, DiLuna ML, Cicchetti DV, Tsevat J, Roberts MS. Cognitive functioning in patients with cerebral aneurysms measured with the Mini Mental State Examination and Telephone Interview for cognitive status. Neurosurgery. 2006; 59:803-11. DOI: 10.1227/01.NEU.0000232666.67779.41

42. Pačić-Turk Lj, Šulentić T, Havelka Meštrović A, Paladino J, Mrak G. Personality changes following brain artery aneurysm surgery. Acta Clin Croat. 2016;55:565-78. doi: 10.20471/ acc.2016.55.04.06

Sažetak

\section{OPORAVAK PAMĆENJA NAKON OPERACIJE ANEURIZME MOŽDANIH ARTERIJA}

\section{Lj. Pačić-Turk, P. Jandrijević i A. Havelka-Meštrović}

Glavni cilj ovog istraživanja bio je utvrditi postoje li u bolesnika nakon operacije aneurizme moždanih arterija deficiti mnestičkih funkcija (numeričkog, radnog, verbalno-mehaničkog, verbalno-logičkog i vizualnog pamćenja) i dolazi li tijekom vremena proteklog od operacije do oporavka mnestičkih funkcija. U istraživanju je sudjelovalo 92 bolesnika, i to 35 (38\%) muškaraca i 57 (62\%) žena, u dobi od 27 do 76 godina. Neuropsihologijska procjena provedena je u Klinici za neurokirurgiju Kliničkog bolničkog centra Zagreb u razdoblju od 1998. do 2012. godine u dva vremenska intervala: u prvih 11 mjeseci nakon operacije i ponovno 12 do 48 mjeseci nakon operacije. Dobiveni rezultati su pokazali da u prvom vremenskom intervalu postoje deficiti verbalno-mehaničkog, verbalno-logičkog i vizualnog pamćenja. U drugom vremenskom intervalu i dalje su bili prisutni deficiti verbalno-logičkog i vizualnog pamćenja, dok su na testu verbalno-mehaničkog učenja i pamćenja dobiveni rezultati pokazali da i dalje postoje poteškoće povezane s kapacitetom pamćenja i krivuljom učenja, a rezultati ispitivanja kratkoročnog i dugoročnog verbalno-mehaničkog pamćenja sada su bili u granicama očekivanih rezultata. Niti u prvom niti u drugom testiranju nije utvrđeno postojanje deficita numeričkog i radnog pamćenja. S obzirom na dobivene rezultate ovog istraživanja može se zaključiti da su se kratkoročno i dugoročno verbalno-mehaničko i vizualno pamćenje statistički značajno oporavili tijekom vremena proteklog od operacije, dok na testovima drugih vrsta pamćenja nije utvrđeno postojanje statistički značajnog oporavka.

Ključne riječi: Intrakranijska aneurizma - kirurgija; Pamćenje, kratkotrajno; Pamćenje, dugotrajno; Pamćenje, poremé́aji; Oporavak funkcije; Hrvatska 